\title{
A Validated Stability Indicating RP-HPLC Method Development and Validation for Simultaneous Estimation of Cefixime Trihydrate and Levofloxacin Hemihydrate in Pharmaceutical Dosage Form
}

\author{
Patel Dhara ${ }^{* 1}$, Meshram Dhananjay $^{1}$, Parmar Vandana ${ }^{1}$, Pathak Devanshi ${ }^{1}$ and Patel Hiral ${ }^{1}$
}

${ }^{1}$ Department of Quality Assurance, Pioneer Pharmacy Degree College, Vadodara, Gujarat, India

Received:08 May, 2017; Accepted: 08 June, 2017; Published: 19 June, 2017

*Corresponding authors: Dhara Patel, Ph D, Associate Professor, Department of Quality Assurance, Pioneer Pharmacy Degree College, Vadodara, Gujarat, India; E-mail: patel.dhara.j@gmail.com

\begin{abstract}
The present study describes the stability indicating RP-HPLC method for simultaneous estimation of Cefixime trihydrate and Levofloxacin hemihydrate in pharmaceutical dosage forms. The proposed RP-HPLC method was developed by using Shimadzu (LC20 AD) system equipped with PDA detector and chromatographic separation was carried out on Phenomenex Luna C18 $(250$ x $4.6 \mathrm{~mm}$ $\mathrm{x} 5 \mu$ ) column at a flow rate of $1 \mathrm{~mL} / \mathrm{min}$. The mobile phase consisted of $0.5 \%$ Glacial acetic acid in water $\mathrm{pH}$ adjusted to 4.5 with ammonia solution: Methanol $(45: 55 \% \mathrm{v} / \mathrm{v})$ and eluents were scanned using PDA detector at $290 \mathrm{~nm}$. The retention time of Cefixime trihydrate and Levofloxacin hemihydrate was found to be 3.07 and $5.40 \mathrm{~min}$, respectively. The method has been validated for linearity, accuracy and precision, LOD, LOQ and system suitability according to ICH Q2R1 Guideline. The validated lowest limit of detection was 1.0990 and $1.0008 \mu \mathrm{g} / \mathrm{mL}$ and lowest limit of quantification was 3.331 and $3.032 \mu \mathrm{g} / \mathrm{ml}$ for Cefixime trihydrate and Levofloxacin hemihydrate respectively. Mean assay was found to be $98.5 \%$ and $100.4 \%$ for Cefixime trihydrate and Levofloxacin hemihydrate. The stability indicating method was developed by subjecting the drugs to stress conditions such as acid and base hydrolysis, oxidation and photoand thermal degradation and the degraded products formed were resolved successfully from the samples.
\end{abstract}

Keywords: Cefixime Trihydrate; Levofloxacin hemihydrates; RPHPLC Method; Forced Degradation

\section{Introduction}

Cefixime trihydrate (CEF) is an oral third generation cephalosporin class of antibiotic. Chemically, it is (6R, 7R)-7\{[2-(2-amino-1,3- thiazol-4-yl)-2(carboxymethoxyimino)acetyl] amino\}-3-ethenyl-8-oxo-5-thia-1 azabicyclo-[4.2.0] oct-2-ene-2 carboxylic acid, clinically used in the treatment of susceptible infections including gonorrhea, otitis media, pharyngitis, lower respiratory-tract infections such as bronchitis, and urinary-tract infections [1,2](Figure 1). It is official in Indian Pharmacopoeia
(IP), British Pharmacopoeia (BP), United States Pharmacopoeia (USP), European Pharmacopoeia (EP), Japanese Pharmacopoeia (JP) [3-7]. Literature survey reveals spectrophotometric, TLC, HPTLC, HPLC and HPCE method for estimation of CEF individually and in combination with other drugs in bulk drugs and human plasma [8-22].<smiles>C=CC1=C(C(=O)O)N2C(=O)[C@H](NC(=O)/C(=N\OCC(=O)O)c3csc(N)n3)[C@H]2SC1</smiles>

Figure 1: Chemical Structure of CEF

Levofloxacin hemihydrates (LEVO) chemically (-)-(S)-9fluoro2,3-dihydro-3-methyl-10-(4-methyl-1-piperazinyl)-7oxo-7H-pyrido[1,2,3-de]-1,4benzoxazine-6-carboxylic acid hemihydrate, is a fluoroquinolone antimicrobials, is the active S-isomer isolated from the racemic ofloxacin [23] (Figure 2). It possesses wide spectrum of antibacterial activity against both Gram positive and Gram-negative bacteria, as well as atypical pathogens such as Mycoplasma, Chlamydia and Legionella [24]. Levofloxacin hemihydrate is official in IP [25]. Numerous HPLC, UV and HILIC/MS/MS has been used to determine drugs in dosage form and biological fluids [26-34].

The International Conference on Harmonization (ICH) guideline entitled "Stability testing of new drug substances and 
<smiles>C[C@@H]1COc2c(N3CCN(C)CC3)c(F)cc3c(=O)c(C(=O)O)cn1c23</smiles>

Figure 2: Chemical structure of LEVO

products" requires that stress testing be carried out to elucidate the inherent stability characteristics of the active substance. An ideal stability-indicating method is one that resolves the drug and its degradation products efficiently. Consequently, the implementation of an analytical methodology to determine CEF and LEVO simultaneously, in presence of its degradation products is rather a challenge for pharmaceutical analyst. Therefore, it was thought necessary to study the stability of CEF and LEVO under acidic, alkaline, oxidative, UV and photolytic conditions. This paper reports validated stability-indicating HPLC method for simultaneous determination of CEF and LEVO in presence of their degradation products. The proposed method is simple, accurate, reproducible, stability-indicating and suitable for routine determination of CEF and LEVO in combined dosage form. The method was validated in compliance with ICH guidelines. The purpose of this study was to develop a stabilityindicating method for the simultaneous determination of CEF and LEVO in bulk drugs and to apply the developed method for the quantitative determination of these drugs from tablets. The RPHPLC technique was chosen because of its previously mentioned advantages. The proposed method was able to separate the compounds of interest and their degradation products within 10 min. Thereafter, this method was validated as per International Conference on Harmonization (ICH) guidelines [35-37]. A literature survey has shown that a stability-indicating HPLC method for the simultaneous determination of CEF and LEVO has not been developed. The previously developed methods have been able to separate both the drugs during a minimum run time, but they were not stability-indicating i.e., the separation of various degradation products, employing ICH prescribed stress conditions, was not achieved [38-40].

\section{Materials and Method}

\section{Chemicals and Reagents}

CEF and LEVO of pharmaceutical grade were kindly supplied as gift samples by Sunrise Remedies, Ahmedabad and Cadila healthcare, Ahmadabad, respectively. Acetonitrile (ACN), methanol, and water used were of HPLC grade and were purchased from Merck specialist Pvt. Ltd, India. Hydrochloric acid, Sodium hydroxide, Hydrogen peroxide was purchased from Suvidhinath Laboratories, India.

\section{Instruments and Equipments}

The liquid chromatographic system was of Shimadzu (LC-20 AD) system and was manufactured by Shimadzu, Kyoto, Japan, equipped with Injector (Rheodyne, $20 \mu \mathrm{L}$ ), UV and photodiode array (PDA) detector. The chromatographic analysis was performed using LC Solution software on a Phenomanex Luna C18 (150X4.6) mm, $5 \mu$ column. In addition, Digital weighing balance (Shimadzu ATX 224, Japan) pH meter (Janki impex Pvt. Ltd), fast clean ultrasonic cleaner (Toshco instrument), hot air oven (Thermolab, Mumbai), humidity cum photostability chamber (Thermolab, Mumbai) were used in this study.

\section{Chromatographic Conditions}

Mobile phase: $0.5 \%$ Glacial acetic acid in Water $\mathrm{pH}$ adjusted to 4.5 with

ammonia solution: methanol (45:55 \% v/v)

Column: Phenomanax Luna C18 (150X4.6) mm, $5 \mu$ Column temperature: $30 \mathrm{oC}$

Injection volume: $20 \mu \mathrm{L}$

Flow rate: $1.0 \mathrm{~mL} / \mathrm{min}$

Wavelength: $290 \mathrm{~nm}$

Diluent: Diluent-1: Water: Methanol (50:50 \% v/v) Stock

Solution Diluent-2: Mobile phase for 2 dilution

\section{Preparation of Mobile Phase}

$450 \mathrm{~mL}$ of pH 4.0 Glacial acetic acid and $550 \mathrm{~mL}$ of methanol were mixed. This mixture was sonicated for $10 \mathrm{~min}$ and filtered through $0.22 \mu \mathrm{m}$ membrane filter and used as mobile phase.

\section{Preparation of $0.5 \%$ Glacial acetic acid (pH 4.5)}

$5 \mathrm{~mL}$ of Glacial acetic acid was added in $1000 \mathrm{~mL}$ of water. Adjusted ph 4.5 with ammonia solution.

\section{Standard Stock Solution Preparation of Cefixime \& Levofloxacin: (100 $\mu \mathrm{g} / \mathrm{mL} \& 125 \mu \mathrm{g} / \mathrm{mL}$ respectively)}

Accurately weighed $25 \mathrm{Mg}$ of Cefixime and $31.25 \mathrm{Mg}$ Levofloxacin were transferred in $50 \mathrm{~mL}$ volumetric flask, then $35 \mathrm{ml}$ of Diluent- 1 added and sonicated for 10 minutes to dissolve it completely. The volume made up with Diluent-1. Pipette out $5 \mathrm{~mL}$ of solution in $25 \mathrm{~mL}$ of volumetric flask and make up the volume with Diluent-2.

\section{Preparation of Sample Solution}

Twenty tablets for combined dosage form of CEF and LEVO were weighed and grind to a fine powder, take label claim quantities of powder equivalent to $25 \mathrm{Mg}$ CEF and 31.25 Mg LEVO were weighed, mixed, and transferred to a $50 \mathrm{ml}$ volumetric flask. The solution was sonicated to dissolve the powder in $30 \mathrm{ml}$ diluents 1 and diluted up to mark with diluents 1 . The solution was filtered through a Whatmann filter paper no. 41 . Take $5 \mathrm{~mL}$ of the above solution and make up to $50 \mathrm{ml}$ with diluents 2 to get 
$100 \mu \mathrm{g} / \mathrm{mL}$ CEF and $125 \mu \mathrm{g} / \mathrm{mL}$ LEVO. A total of $20 \mu \mathrm{L}$ volume of the above sample solution was injected into HPLC and peak areas were measured under optimized chromatographic conditions.

\section{Method Validation}

The method of analysis was validated as per the recommendations of ICH and USP for the parameters like specificity, accuracy, linearity, precision, detection limit, quantification limit, and robustness. Specificity was determined by evaluating the ability of the proposed method to separate CEF and LEVO from its potential degradation products. Forced degradation studies were performed for bulk drug and formulation to provide an indication of the stability-indicating property and specificity of the proposed method. The accuracy of the method was determined by calculating the percentage recovery of CEF and LEVO. For both the drugs, recovery studies were carried out by applying the method to drug sample to which known amount of CEF and LEVO corresponding to 80,100 and $120 \%$ of label claim had been added (standard addition method). Intraday and interday precision study of CEF and LEVO was carried out as per guideline. The Limit of Detection (LOD) and Limit of Quantification (LOQ) were calculated using the following formula:

\section{$\mathrm{LOD}=3.3(\mathrm{SD}) / \mathrm{S}$ and $\mathrm{LOQ}=10(\mathrm{SD}) / \mathrm{S}$}

Where,

$\mathrm{SD}=$ standard deviation of response (peak area)

$\mathrm{S}=$ average of the slope of the calibration curve.

System suitability tests are an integral part of chromatographic method, which are used to verify reproducibility of the chromatographic system. To ascertain its effectiveness, certain system suitability test parameters were checked by repetitively injecting the drug solution to check the reproducibility of the system. For robustness evaluation of HPLC method a few parameters like flow rate, percentage of methanol in the mobile phase and $\mathrm{pH}$ of mobile phase were deliberately changed. One factor was changed at one time to estimate the effect.

\section{Forced Degradation Studies}

Forced degradation studies of both the drugs were carried out under conditions of hydrolysis, dry heat, oxidation, and photolysis.

\section{Sample Stock Preparation for Forced Degradation Study}

Transferred 5 intact tablets in to $200 \mathrm{~mL}$ of volumetric flask, added about $150 \mathrm{~mL}$ of Diluent- 1 in to it, sonicated for 30 minutes with intermittent shaking, cooled to attain room temperature and made up to volume with Diluent- 1 and filtered the solution with $0.45 \mu$ nylon filter.

\section{Sample Preparation for Acidic Degradation}

$1 \mathrm{~mL}$ of above sample stock solution filtrate was transferred to $100 \mathrm{~mL}$ of Volumetric Flask; added $5 \mathrm{~mL}$ of $1 \mathrm{~N} \mathrm{HCl}$ to it and it was kept for 3 hours at room temperature. Then added $5 \mathrm{~mL}$ of $1 \mathrm{~N} \mathrm{NaOH}$ to neutralize it and volume was made up to mark with Diluent-2, mixed well and injected.

\section{Sample Preparation for Basic Degradation}

$1 \mathrm{~mL}$ of above sample stock solution filtrate was transferred to $100 \mathrm{~mL}$ of Volumetric Flask; added $5 \mathrm{~mL}$ of $1 \mathrm{~N}$ $\mathrm{NaOH}$ to it and it was kept for 2 hours at room temperature. Then added $5 \mathrm{~mL}$ of $1 \mathrm{~N} \mathrm{HCl}$ to neutralize it and volume was made up to mark with Diluent-2, mixed well and injected.

\section{Sample Preparation for Peroxide Degradation}

$1 \mathrm{~mL}$ of above sample stock solution filtrate was transferred to $100 \mathrm{~mL}$ of Volumetric Flask; added $5 \mathrm{~mL}$ of $3 \%$ $\mathrm{H} 2 \mathrm{O} 2$ to it and it was kept for 2 hours at room temperature. Then volume was made up to mark with Diluent- 2 and mixed well and injected.

\section{Sample Preparation for Thermal Degradation}

$1 \mathrm{~mL}$ of above sample stock solution filtrate was transferred to $100 \mathrm{~mL}$ of Volumetric Flask; it was kept for 3 hours at $80^{\circ} \mathrm{C}$ temperature. Then volume was made up to mark with Diluent-2 and mixed well and injected.

\section{Sample Preparation for Sunlight Degradation}

$1 \mathrm{~mL}$ of above sample stock solution filtrate was transferred to $100 \mathrm{~mL}$ of Volumetric Flask; it was kept for 12 hours in sunlight. Then volume was made up to mark with Diluent- 2 and mixed well and injected.

\section{Results and Discussions}

\section{Method Development}

A series of trials was conducted with different columns like Phenomanax Luna C18 and and C-8 columns with different mobile phases to develop a suitable RP-HPLC method for estimation of CEF and LEVO in tablet dosage form, and finally a typical chromatogram was obtained with isocratic elution of mobile phase consisting of $0.5 \%$ Glacial acetic acid in Water $\mathrm{pH}$ adjusted to 4.5 with ammonia solution : Methanol (45:55 \% v/v), and at flow rate of $1.0 \mathrm{~mL} / \mathrm{min}$ The chromatographic separation was performed on Phenomanax Luna C18 (150X4.6) mm, $5 \mu$ by injecting $20 \mu \mathrm{L}$ and analytes were detected with PDA detector at $290 \mathrm{~nm}$. The retention time of CEF and LEVO was found to be $3.012 \mathrm{~min}$ and $5.40 \mathrm{~min}$, respectively (Figure 3). Forced degradation studies were also carried using the developed method and the degraded compounds were effectively resolved from the CEF and LEVO in tablet dosage form. The optimized conditions were given in (Table 1).

\section{Method Validation}

\section{System Suitability}

System suitability was performed to verify the acceptability of the resolution and repeatability of the system. System suitability was performed by injecting six replicate injections of the standard solution (100\%) and parameters such 


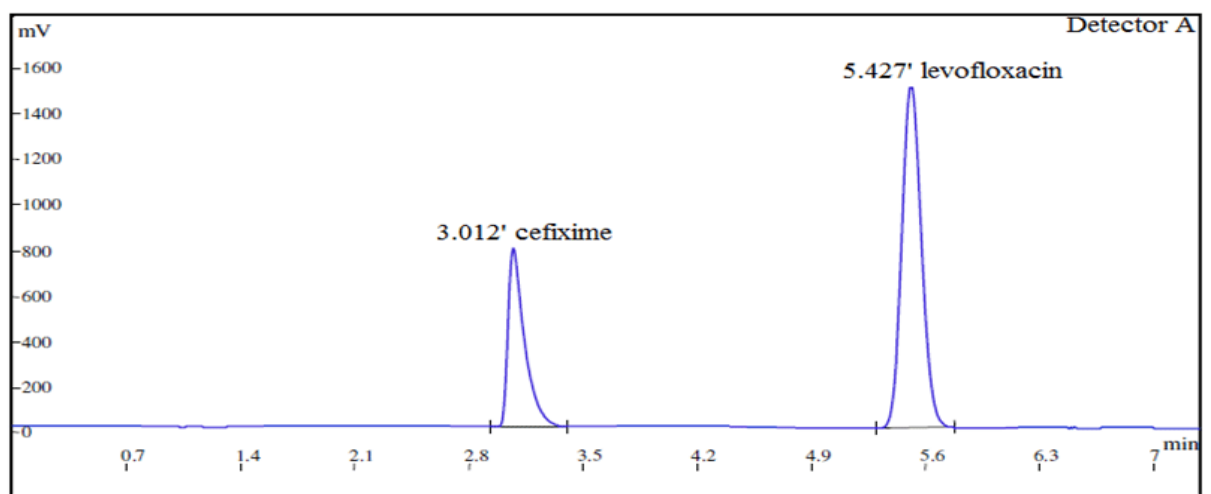

Figure 3: Optimised chromatogram of CEF and LEVO

Table 1: Optimized Chromatographic Conditions

\begin{tabular}{|l|l|l|}
\hline Sr. no & Parameters & Optimized Chromatographic Condition \\
\hline 1 & Column & Phenomanax Luna C18 (150X4.6) $\mathrm{mm}, 5 \mu$ \\
\hline 2 & Mobile Phase & $\begin{array}{l}0.5 \% \text { Glacial acetic acid in Water } \mathrm{pH} \\
\text { adjusted to } 4.5 \mathrm{with} \text { ammonia solution : } \\
\text { Methanol }(45: 55 \% \mathrm{v} / \mathrm{v})\end{array}$ \\
\hline 3 & Flow rate & $1.0 \mathrm{~mL} / \mathrm{min}$ \\
\hline 4 & Detector & PDA detector at $290 \mathrm{~nm}$ \\
\hline 5 & Injection Volume & $20 \mu \mathrm{L}$ \\
\hline 6 & Temperature & $30^{\circ} \mathrm{C}$ \\
\hline 7 & Retention time & $\begin{array}{l}\text { CEF } 3.012 \mathrm{~min} \\
\mathrm{LEVO} 5.40 \mathrm{~min}\end{array}$ \\
\hline
\end{tabular}

as peak area, USP tailing, theoretical plates, retention time, and peak asymmetry were evaluated. The $\%$ RSD was determined and reported within the limits. The results were shown in (Table 2).

\section{Linearity}

The peak area was dynamic-linear in the concentration ranges of 80.1-120.1 $\mathrm{mg} \mathrm{mL}^{-1}$ for CEF and 100.1-150.1 $\mathrm{mg} \mathrm{mL}^{-1}$ for LEVO, respectively. Highly significant correlation coefficient demonstrated the linearity of the method (Table 3 and Figure 4).

\begin{tabular}{|c|c|c|}
\hline Table 2: Data of system suitability \\
\hline Parameters & CEF & LEVO \\
\hline $\begin{array}{c}\text { Retention time } \\
\text { (minute) }\end{array}$ & 3.072 & 5.401 \\
\hline Resolution & \multicolumn{2}{|c|}{7.9} \\
\hline Theoretical Plates & 11248 & 10254 \\
\hline Tailing Factor & 1.1 & 1.1 \\
\hline
\end{tabular}

\begin{tabular}{|c|c|c|}
\hline \multicolumn{3}{|c|}{ Table 3: Parameters of regression analysis } \\
\hline Parameters & CEF & LEVO \\
\hline $\begin{array}{c}\text { Linearity } \\
\left(\mathrm{mg} \mathrm{mL}^{-1}\right)\end{array}$ & $80.1-120.1$ & $100.1-150.1$ \\
\hline $\begin{array}{c}\text { Correlation coef- } \\
\text { ficient }\left(\mathrm{R}^{2}\right)\end{array}$ & 0.9998 & 0.9990 \\
\hline Slope & 65592.486 & 80164.266 \\
\hline Intercept & 86857.404 & 111778.210 \\
\hline
\end{tabular}

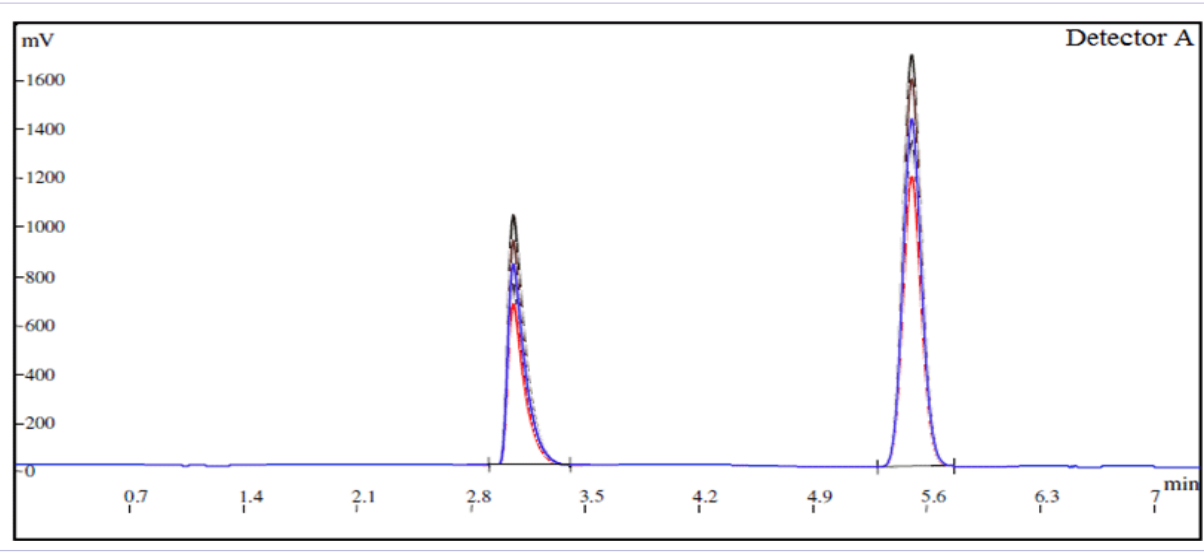

Figure 4: Overlain Chromatogram of CEF and LEVO (Linearity) 


\section{Specificity}

The chromatograms of blank, placebo, test sample, and standard were used to justify the specificity of target analyte. The method was specific since excipients in the formulation did not interfere in the estimation of CEF and LEVO (Figure 5).

\section{Accuracy}

The accuracy of the proposed method was evaluated by calculating the recovery studies of the test drug at three different concentration levels (80\%, $100 \%$, and $120 \%$ ) by standard addition method. A known amount of CEF and LEVO was added to prequantified sample solution and three replicates of each concentration were injected in developed chromatographic conditions. The \% recovery results were shown in (Table 4).

\section{Precision}

The values of \%RSD for intraday and interday variation were found very well and within $2 \%$ limit, indicating that the current method is repeatable (Table 5).

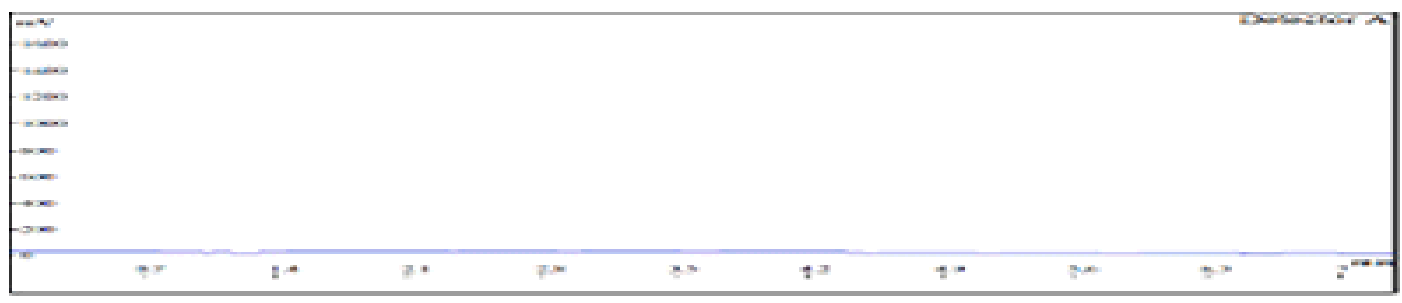

(a)

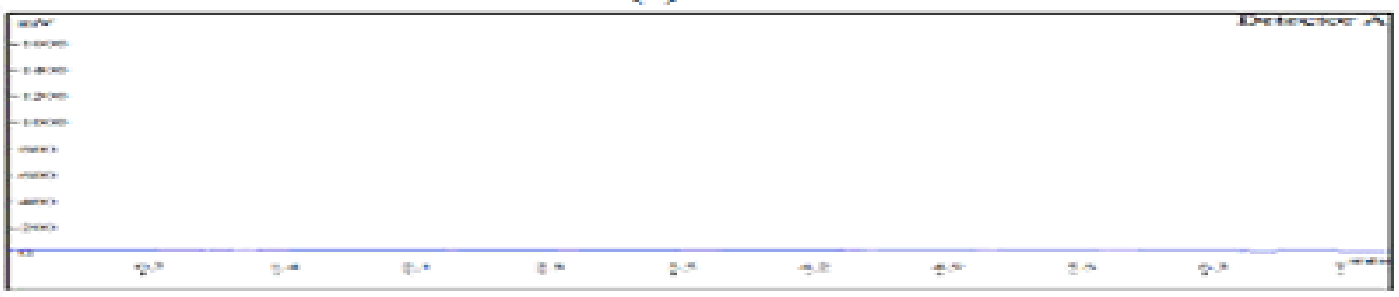

(b)

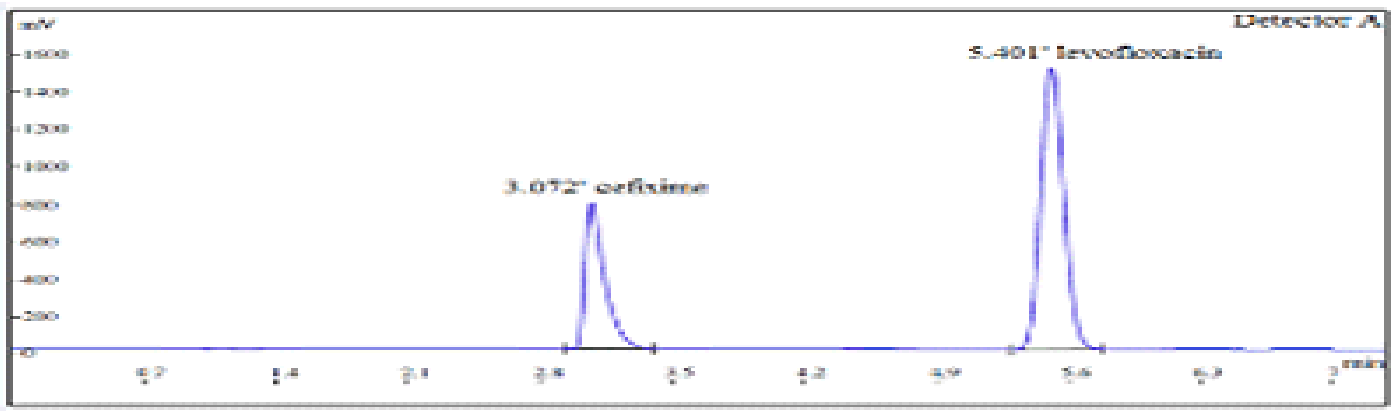

(c)

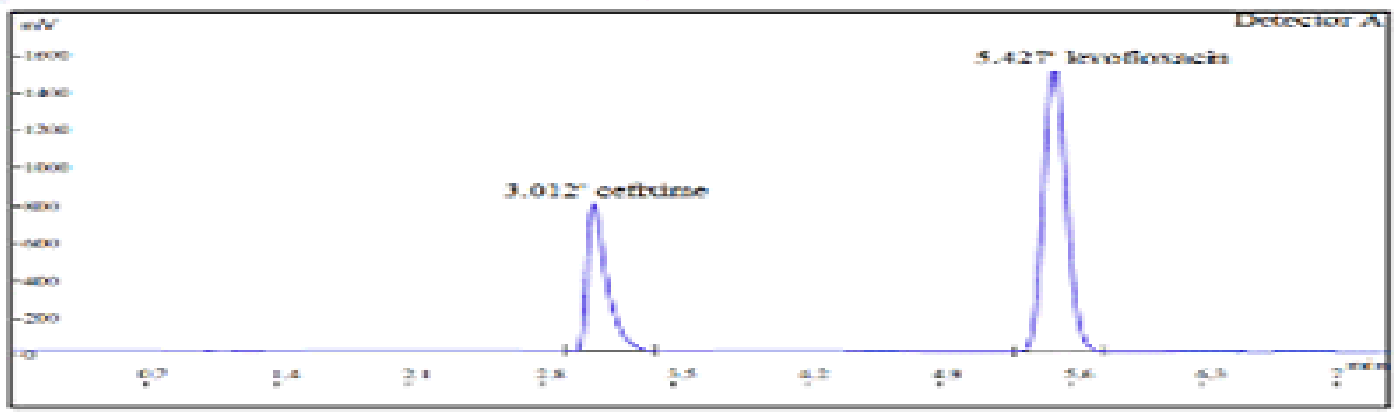

(a)

Figure 5: Chromatogram of CEF and LEVO (a) Blank (b) Placebo (c) Standard and (d) formulation 

Simultaneous Estimation of Cefixime Trihydrate and Levofloxacin Hemihydrate in Pharmaceutical Dosage Form

\begin{tabular}{|c|c|c|c|c|}
\hline \multirow{2}{*}{$\begin{array}{l}\text { Spiked } \\
\text { Level }\end{array}$} & \multicolumn{2}{|c|}{ \%Recovery } & \multicolumn{2}{|c|}{$\%$ RSD } \\
\hline & $\mathrm{CEF}$ & LEVO & $\mathrm{CEF}$ & LEVO \\
\hline \multirow[t]{3}{*}{$80 \%$} & 98.5 & 101.3 & \multirow{3}{*}{0.7} & \multirow[b]{3}{*}{0.3} \\
\hline & 99.3 & 101.4 & & \\
\hline & 99.8 & 100.8 & & \\
\hline \multirow[t]{3}{*}{$100 \%$} & 99.3 & 101.5 & \multirow{3}{*}{0.5} & \multirow{3}{*}{0.7} \\
\hline & 98.8 & 100.9 & & \\
\hline & 98.3 & 100.1 & & \\
\hline \multirow[t]{3}{*}{$120 \%$} & 99.0 & 100.7 & \multirow{3}{*}{0.4} & \multirow{3}{*}{0.5} \\
\hline & 98.4 & 100.2 & & \\
\hline & 99.0 & 101.2 & & \\
\hline
\end{tabular}

\section{Sensitivity}

in (Table 6).

The Data for the LOD and LOQ for CEF and LEVO Shown

\section{Robustness}

The effects of robustness study under different altered conditions of this proposed method are satisfactory (Table 7). The mean recovery and \% RSD of analyzed sample indicate that the current method is robust.

\section{Assay of Marketed Formulation}

The $\%$ assay of the marketed formulation was found to be $98.5 \%$ for CEF and $100.4 \%$ for LEVO (Table 8).

Table 5: Result of precision of CEF and LEVO

\begin{tabular}{|c|c|c|c|c|c|}
\hline Drug & $\begin{array}{l}\text { Sample Concentration } \\
\qquad\left(\mathrm{mg} \mathrm{mL}^{-1}\right)\end{array}$ & Peak Area(Day 1) & Overall $\pm \%$ RSD & Peak Area(Day 2) & Overall $\pm \%$ RSD \\
\hline \multirow[t]{15}{*}{$\mathrm{CEF}$} & \multirow[t]{5}{*}{90.1} & 5820537 & \multirow[t]{5}{*}{$5820089 \pm 0.011$} & & \multirow[t]{5}{*}{$5814440 \pm 0.074$} \\
\hline & & & & 5812345 & \\
\hline & & 5820414 & & & \\
\hline & & & & 5819413 & \\
\hline & & 5819315 & & 5811563 & \\
\hline & \multirow[t]{5}{*}{100.1} & 6471128 & \multirow[t]{5}{*}{$6434480 \pm 0.49$} & & \multirow[t]{5}{*}{$6427121 \pm 0.58$} \\
\hline & & & & 6469852 & \\
\hline & & 6421088 & & & \\
\hline & & & & 6411256 & \\
\hline & & 6411225 & & 6400256 & \\
\hline & \multirow[t]{5}{*}{110.1} & 7115843 & \multirow[t]{5}{*}{$7136223 \pm 0.79$} & & \multirow[t]{5}{*}{$7106106 \pm 0.24$} \\
\hline & & & & 7101236 & \\
\hline & & 7092813 & & & \\
\hline & & & & 7091452 & \\
\hline & & 7200013 & & 7125631 & \\
\hline \multirow[t]{9}{*}{ LEVO } & 112.6 & 8907099 & \multirow[t]{3}{*}{$8943751 \pm 0.66$} & 8906512 & \multirow[t]{3}{*}{$8907659 \pm 0.02$} \\
\hline & & 8912135 & & 8910235 & \\
\hline & & 9012018 & & 8906231 & \\
\hline & 125.1 & 9913240 & \multirow[t]{3}{*}{$9902636 \pm 0.17$} & 9902563 & \multirow{3}{*}{$\begin{array}{c}9865203 \\
\pm 0.46\end{array}$} \\
\hline & & 9882151 & & 9878456 & \\
\hline & & 9912516 & & 9814589 & \\
\hline & 137.6 & 10100862 & \multirow{3}{*}{$\begin{array}{l}10135213 \\
\pm 0.40\end{array}$} & 10800730 & \multirow{3}{*}{$\begin{array}{c}10864134 \\
\pm 0.50\end{array}$} \\
\hline & & 10181215 & & 10891458 & \\
\hline & & 10123561 & & 10900214 & \\
\hline
\end{tabular}



Simultaneous Estimation of Cefixime Trihydrate and Levofloxacin Hemihydrate in Pharmaceutical Dosage Form

Table 6: LOD and LOQ data for CEF and LEVO

\begin{tabular}{|c|c|c}
\hline \multicolumn{1}{|c|}{ Limit of Detection (LOD) } & LEVO \\
\hline $1.10 \mu \mathrm{g} / \mathrm{Ml}$ & $1.00 \mu \mathrm{g} / \mathrm{mL}$ \\
\hline & Limit of Quantitation & $3.03 \mu \mathrm{g} / \mathrm{Ml}$ \\
\hline $3.33 \mu \mathrm{g} / \mathrm{mL}$ & \\
\hline
\end{tabular}

Table 7: Robustness data for CEF and LEVO

At Normal Range (CEF)

Flow rate $1 \mathrm{ml} / \mathrm{min}$

Mobile phase (45:55)

$\mathrm{pH} 4.5$

\begin{tabular}{|c|c|c|c|c|c|c|}
\hline Sr. No. & $\begin{array}{c}\text { Flow rate } \\
+0.1\end{array}$ & $\begin{array}{c}\text { Flow rate } \\
-0.1\end{array}$ & M.P + 2 & M.P - 2 & $\mathrm{pH}+0.2$ & pH - 0.2 \\
\hline 1 & 5847283 & 7068145 & 8897643 & 6438437 & 9843851 & 6420128 \\
\hline 2 & 5835432 & 7021756 & 8881317 & 6418546 & 9836270 & 6392656 \\
\hline 3 & 5792291 & 7007583 & 8897218 & 6448751 & 9792430 & 6430960 \\
\hline \%RSD & 0.5 & 0.5 & 0.5 & 0.5 & 0.3 & 0.3 \\
\hline \multicolumn{6}{|c|}{ At Normal Range (LEVO) } & Peak Area $\pm \%$ RSD \\
\hline \multicolumn{6}{|c|}{ Flow rate $1 \mathrm{ml} / \mathrm{min}$} & \multirow[t]{3}{*}{$9849881 \pm 0.14$} \\
\hline \multicolumn{6}{|c|}{ Mobile phase (45:55) } & \\
\hline \multicolumn{6}{|c|}{$\mathrm{pH} 4.5$} & \\
\hline 1 & 8833112 & 10864522 & 9765496 & 9876432 & 9838124 & 9757021 \\
\hline 2 & 8877220 & 10874268 & 9833987 & 9890048 & 9859416 & 9836270 \\
\hline 3 & 8881317 & 10834869 & 9784174 & 9865372 & 9865372 & 9792430 \\
\hline \%RSD & 0.5 & 0.2 & 0.5 & 0.2 & 0.2 & 0.4 \\
\hline
\end{tabular}


Table 8: \% Assay of marketed formulation

\begin{tabular}{|c|c|c|c|}
\hline Drug & Label claim & $\begin{array}{l}\text { Amt. of drug esti- } \\
\text { mated }\end{array}$ & \% Label claim \\
\hline CEF & $400 \mathrm{mg}$ & $394 \mathrm{mg}$ & $98.5 \%$ \\
\hline LEVO & $500 \mathrm{mg}$ & $502 \mathrm{mg}$ & $100.4 \%$ \\
\hline
\end{tabular}

\section{Forced Degradation Studies}

In the present study forced degradation studies were carried out to ensure the effective separation of CEF and LEVO from degradation products. Degradation was observed by decreasing the peak areas of the drug substances with same drug molecules of degraded peak areas. The percentage assay of degradation was calculated from the peak area obtained in degradation conditions and it was compared with assay of nondegraded conditions. Acidic and alkali degradation was carried out by treating the sample solution with $1 \mathrm{~N} \mathrm{HCl}$ and $1 \mathrm{~N} \mathrm{NaOH}$ solutions. Oxidative degradation studies were performed by treating $3 \%$ $\mathrm{H}_{2} \mathrm{O}_{2}$ solution and keeping it at room temperature for $3 \mathrm{~h} \mathrm{~min}$. For thermal stress studies the drug solutions were placed in oven at $80^{\circ} \mathrm{C}$ for $3 \mathrm{~h}$ and then injected into HPLC system and sunlight testing was carried out by keeping the drug solutions in sunlight for $12 \mathrm{hrs}$ from the chromatograms, it was found that both the molecules are susceptible to acidic, alkali, oxidative, thermal and sunlight degradation and percentage assay degradation in all the conditions was found to be within the limits (Figure 6-10). The forced degradation studies were performed without intending to identify the degradation products but merely to show that they are not interfering with active molecules if any present. The results of stress studies were shown in (Table 9 and 10).

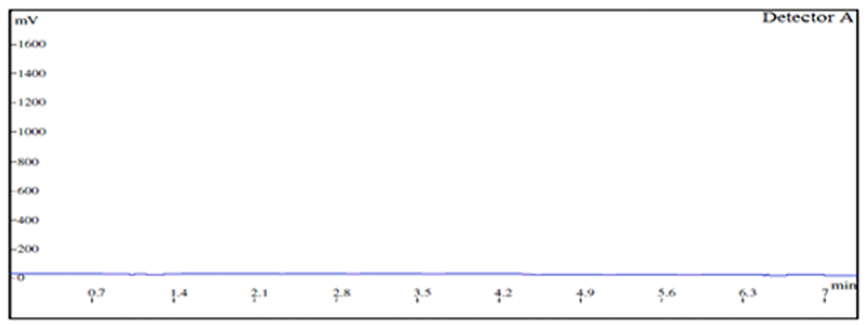

(a)

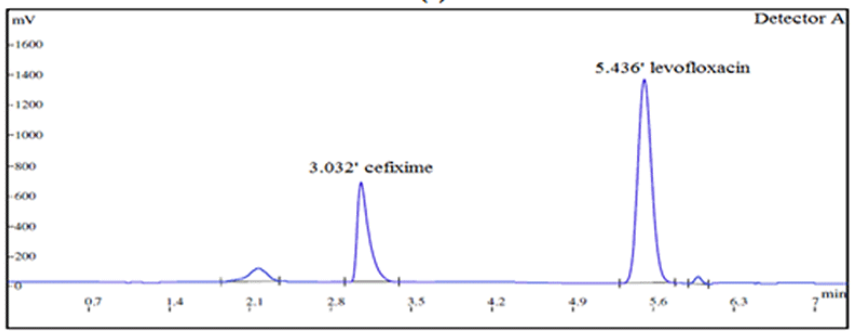

(b)

Figure 6: Acidic stress degradation chromatogram of (a) Blank (b) Formulation

Table 9: Retention time of degradant product of CEF and LEVO (Stress Degradation Study)

\begin{tabular}{|c|c|c|c|c|c|}
\hline \multirow[t]{2}{*}{ Conditions } & \multicolumn{5}{|c|}{ Retention time (Rt) (minute) } \\
\hline & CEF & LEVO & Degradant1 & Degradant2 & Degradant3 \\
\hline $\begin{array}{l}\text { Acid Degrada- } \\
\text { tion }\end{array}$ & 3.03 & 5.43 & 2.15 & 6.00 & ---------- \\
\hline $\begin{array}{l}\text { Base Degrada- } \\
\text { tion }\end{array}$ & 3.05 & 5.48 & 2.15 & 5.03 & ------------- \\
\hline $\begin{array}{l}\text { Peroxide Degra- } \\
\text { dation }\end{array}$ & 3.05 & 5.46 & 3.56 & 5.01 & ------------ \\
\hline $\begin{array}{l}\text { Thermal Degra- } \\
\text { dation }\end{array}$ & 3.04 & 5.46 & 2.30 & 3.59 & 4.99 \\
\hline $\begin{array}{l}\text { Sunlight Degra- } \\
\text { dation }\end{array}$ & 3.04 & 5.4 & 3.60 & 5.11 & ------------ \\
\hline
\end{tabular}



Simultaneous Estimation of Cefixime Trihydrate and Levofloxacin Hemihydrate in Pharmaceutical Dosage Form

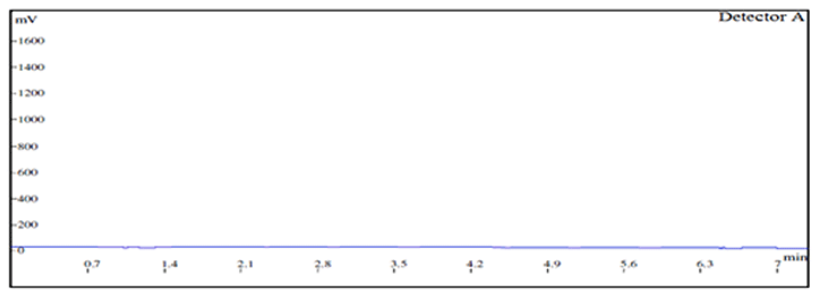

(a)

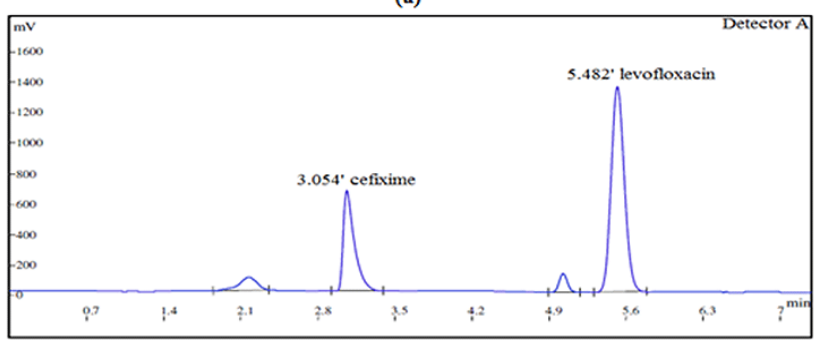

(b)

Figure 7: Alkaline stress degradation chromatogram of (a) Blank (b) Formulation

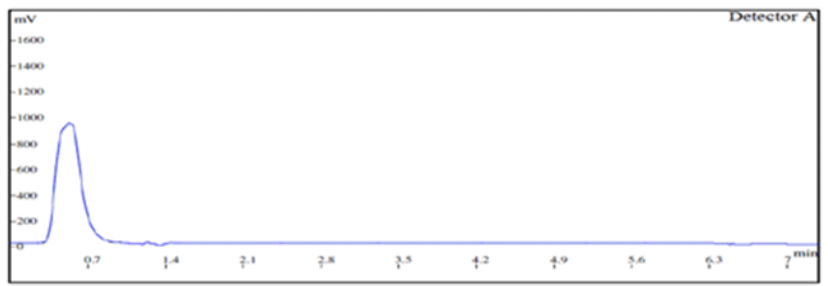

(a)

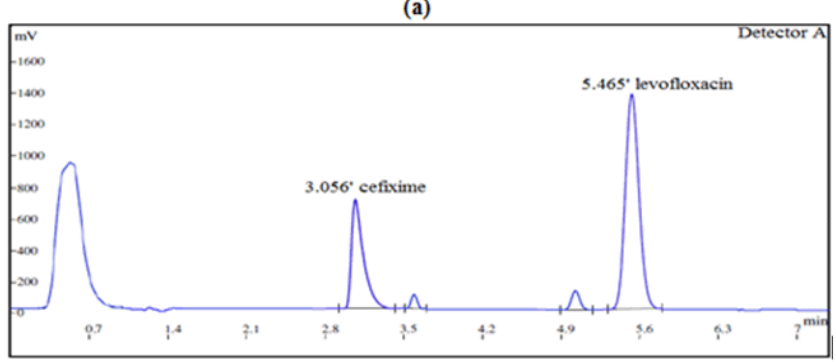

(b)

Figure 8: Oxidative stress degradation chromatogram of (a) Blank (b) Formulation

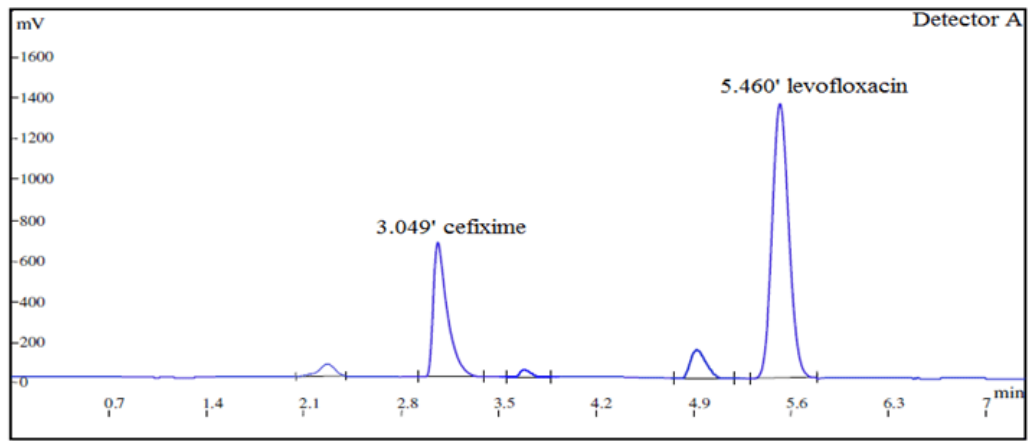

Figure 9: Thermal stress degradation chromatogram of Formulation 


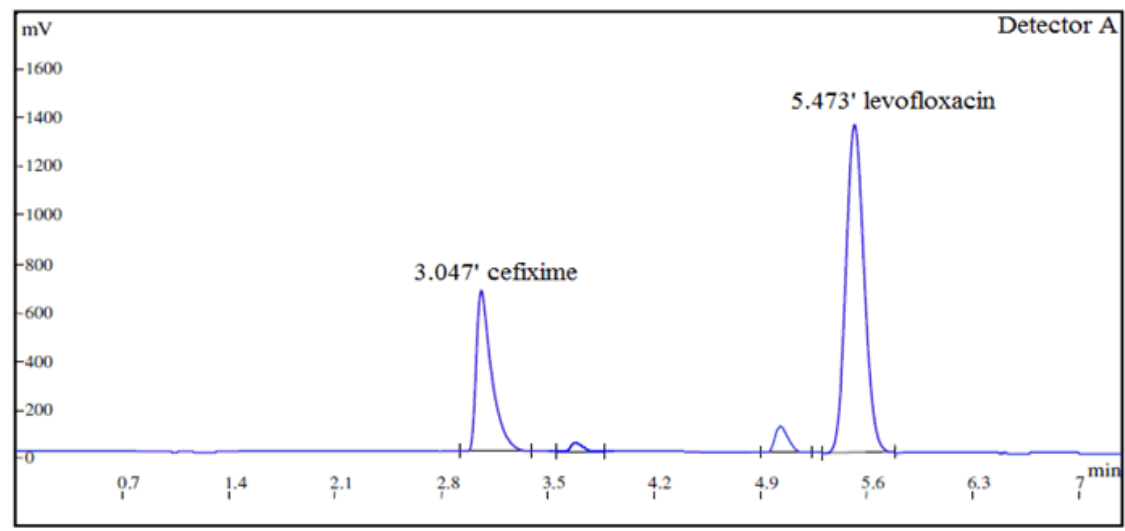

Figure 10: Sunlight stress degradation chromatogram of Formulation

Table 10: Results of Forced degradation studies

\begin{tabular}{|c|c|c|c|c|c|c|}
\hline \multirow[t]{2}{*}{ Stress type } & \multirow[t]{2}{*}{ Stress conditions } & \multicolumn{2}{|c|}{ CEF } & \multicolumn{3}{|c|}{ LEVO } \\
\hline & & $\%$ Assay & \%Degradation & \% Assay & $\%$ & $\begin{array}{l}\text { Degrada- } \\
\text { tion }\end{array}$ \\
\hline Control Sample & Sample itself & 98.5 & NA & 100.4 & & NA \\
\hline Acid Degradation & $\begin{array}{c}1 \mathrm{~N} \mathrm{HCL}, \\
5 \mathrm{~mL} \text { for } 3 \text { hours }\end{array}$ & 87.1 & 11.4 & 85.9 & & 14.5 \\
\hline Base Degradation & $\begin{array}{c}1 \mathrm{~N} \mathrm{NaOH}, \\
5 \mathrm{ml} \text { for } 5 \text { hours }\end{array}$ & 80.9 & 17.6 & 87.2 & & 13.2 \\
\hline Peroxide Degradation & $\begin{array}{c}5 \mathrm{~mL} 3 \% \mathrm{H}_{2} \mathrm{O}_{2} \text { at } \\
\mathrm{RT} \\
\text { for } 3 \text { hours }\end{array}$ & 88.3 & 10.2 & 88.1 & & 13.2 \\
\hline Thermal Degradation & At $80^{\circ} \mathrm{C}$ for 3 Hours & 87.2 & 11.3 & 86.9 & & 13.5 \\
\hline Sunlight Degradation & $\begin{array}{c}\text { At sunlight for } 12 \\
\text { hours }\end{array}$ & 86.8 & 11.7 & 87.1 & & 13.3 \\
\hline
\end{tabular}

\section{Conclusion}

The reported RP-HPLC method was proved to be simple, rapid, and reproducible. The validation data indicate good precision, accuracy, and reliability of the method. The developed method offers several advantages in terms of simplicity in mobile phase, isocratic mode of elution, easy sample preparation steps, and comparative short run time which makes the method specific and reliable for its intended use in simultaneous determination of CEF and LEVO in tablet dosage form. Quick stability indicating RP-HPLC method was developed for the simultaneous estimation of CEF and LEVO in the presence of its degradation products, generated from forced degradation studies. The developed method separates CEF and LEVO in impurities/degradation products. There were no reported stability indicating methods for this combination of drugs in liquid dosage form; hence, this method has an advantage of being unique and novel.

\section{Acknowledgement}

The authors greatly thankful to Sunrise Remedies, Ahmedabad and Cadila healthcare, Ahmedabad, for providing the gift sample of Cefixime trihydrate and Lecofloxacin hemihydrates. Authors also extend their thanks to the management, Pioneer Pharmacy Degree College, Vadodara for providing the facilities to carry out the present work.

\section{References}

1. Maryadele J, O'Neil. The Merck Index: An Encyclopedia of Chemicals, Drugs, and Biologicals. 14th ed. USA: Whitehouse Station NJ: Merck 2006. 986.

2. Rang HP, Dale MM, Ritter JM and Flower RJ. Book of Pharmacology. 8thed. Elsevier's Publication; 2015. 666-672.

3. Indian Pharmacopoeia Government of India. The Controller of Publication, New Delhi, Addendum. 2008;2377-78.

4. British Pharmacopoeia. Vol I. 6thed. Her Majesty's Stationary Office. 
London, 2010. 410

5. The United State Pharmacopoeia. 28th ed. Rockville: The United States Pharmacopoeial Convention Inc. 2005;1413-15.

6. European Pharmacopoeia, Supplement 6.0, Vol-II, 6thed, Council Europe Strasbourg, 2007;1450-52, 2541-42.

7. Japanese Pharmacopoeia, 15th ed. Society of Japanese Pharmacopoeia, Tokyo,; 443,. 2006.p. 938-939.

8. Falkowski AJ, Look ZM. Determination of Cefixime in biological Samples by reversed-phase high-performance liquid chromatography. J Chromatogr B Biomed Sci Appl. 1987;422:145-152.

9. Eric JS, Agbaba D, Zivanov S, Vladimirov S. HPTLC Determination of Cephalosporins in Dosage Forms. J. Pharm. Biomed. Anal. 1998;18:893-898.

10. Honda S, Taga A, Kakehi K, Koda S, Okamoto Y. Determination of Cefixime and it's Metabolites by High Performance Capillary Electrophoresis. J Chromatogr. 1992;590 (2):364-368.

11. Arshad HM, Gauhar S, Bano R, Muhammad DIN. Development of HPLC-UV method for Analysis of Cefixime In Raw Material and In Capsule. Jordan Journal of Pharmaceutical Sciences. 2009;2(1):53-64.

12. Virypaxappa BS, Shivaprasad KH, Latha MS. A Simple Method for Spectrophotometric Determination of Cefixime in Pharmaceuticals Analytical Chemistry An Indian Journal. 2010; 9(1):108-112.

13. Dhoka MV, Vaidya PD, Pande AV, Arora AA. Development and Validation of Analytical Method for Estimation of Cefixime in Swab Samples. Int.J. ChemTech Res. 2010;2(4):1918-1923.

14. Singh BK, Parwate DV, Srivastava S, Shukla SK. Thin-Layer Chromatographic Selective and Stability-Indicating Method for Assay of Cefixime in Pharmaceuticals. J. Planar. Chromatogr. 2011;24 (6):524- 528.

15.Dhoka MV, Gawande VT, Joshi PP. Validated HPTLC method for Determination of Cefixime Trihydrate and Erdosteine in Bulk and combination Pharmaceutical Dosage form. Eurasian J Anal Chem. 2013;8(3):99-106.

16. Ramesh M, Kanaka DM, Sravani A, Snehalatha T, Thimmareddy D. A New Stability Indicating Validated RP-HPLC Method for the Simultaneous Estimation of Azithromycin and Cefixime in Bulk and Pharmaceutical Dosage Forms. Asian J Chem. 2012;5(8):1067-1073.

17. Khandagle KS, Gandhi SV, Deshpande PB, Kale AN, Deshmukh PR HPTLC Determination of Cefiximetrihydrate and Ofloxacin in Combined Tablet Dosage Form. J Chem Pharm Res. 2010;2(5):92-96.

18. Devika GS, Sudhakar M, Rao VJ. Validated TLC Densitometric method for the quantification ofCefiximeTrihydrate and Ornidazole in bulk drug and in tablet dosage form. Der Pharma Chemica. 2010;2(6):97104.

19. Basu A, Basak K, Chakraborty M, Singh RI. Development and Validation of High Performance Liquid Chromatographic Method for Simultaneous Estimation of Potassium Clavulanate and Cefixime Trihydrate in Tablet Dosage Form. J Pharm Res. 2011;4(5):1319-1321.

20. Pawar SJ, Kale AP, Amrutkar MP, Jagade JJ, Pore NS, Bhosale AV. HPTLC Estimation of Cefixime and Cloxacillin in Tablet Dosage Form. Asian J Research Chem. 2010;3(2):299- 301.

21. Deshpande MM, Kastureb V, Gosavi SA. Application of HPLC and HPTLC for the Simultaneous Determination of Cefixime Trihydrate and Ambroxol Hydrochloride in Pharmaceutical Dosage Form. Eurasian J Anal Chem. 2010;5(3):227-238.
22.Zendelovska D, Stafilov T, Milosevski P. HPLC method for determination of Cefixime and Cefotaxime in human plasm. Bulletin of the Chemists and Technologists of Macedonia. 2003;22(1):39-45.

23. Sweetman SC. Martindale: The Complete Drug Reference. 32nd ed. London: The Pharmaceutical Press; 1999. 4142.

24. Oneil MJ, Smith A, Heckelman PE. The Merck Index: an encyclopedia of chemicals, drugs, and biologicals / Susan Budavari, editor emeritus. 13th ed. USA: Whitehouse Station NJ: Merck 2001.

25. Indian Pharmacopoeia, Government of India Ministry of Health and Family Welfare. Published by the IP Commission. Gaziabad. 2010;1579-1580:1823-1824

26. Kumar T, Chitra A, Amrithraj V, andKumar N. New RP-HPLC Method Development and Validation for Estimation of Levofloxacin in Tablet Dosage Form. J Global Trends Pharm Sci. 2011;2(3):264-276.

27. Lakka NS and Goswami N. A Novel Isocratic RP-HPLC Method Development and Validation for Estimation of 5HMF in Levofloxacin Hemihydrate Intravenous Infusion. Int. J. Res. Pharm. Sci. 2011;2(1):45-51.

28. Djabarouti S, Boselli E, Allaouchiche B, Ba B, Nguyen AT, Gordien JB, et al. Determination of Levofloxacin in Plasma, Bronchoalveolar Lavage and Bone Tissues by High Performance Liquid Chromatography with Ultraviolet Detection Using a Fully Automated Extraction Method. J Chromatogr B Analyt Technol Biomed Life Sci. 2004;799(1):165-72.

29. Liang H, Kays MB and Sowinski KM. Separation of Levofloxacin, Ciprofloxacin, Gatifloxacin, Moxifloxacin, Trovafloxacin and Cinoxacin by High-Performance Liquid Chromatography: Application to Levofloxacin Determination in Human Plasma. J Chromatogr B Analyt Technol Biomed Life Sci. 2002;772(1):53-63.

30. Mehta J, Pancholi Y, Patel V, Kshatri N, Vyas N. Development and Validation of a Sensitive Stability Indicating Method for Quantification of Levofloxacin Related Substances and Degradation Products in Pharmaceutical Dosage Form. Int J PharmTech Res. 2010;2(3):1932-1942.

31. Bottcher S, Von BH, Hoppe-Tichy T, Benz C, Sonntag HG. An HPLC assay and a Microbiological Assay to Determine Levofloxacin in Soft Tissue, Bone, Bile and Serum. J Pharm Biomed Anal. 2001;25(2):197-203.

32. Sheikh NW, Tripathi AS, Chitra V, Choudhury A and Dewani AP. Development and Validation of RP-HPLC Assay for Levofloxacin in Rat Plasma and Saliva: Application to Pharmacokinetic Studies. Afr. J. Pharm. Pharmacol. 2011;5(13):1612-1618.

33. Rahar S, Dogra S, Panchru D, Singh P and Shah G. Development and Validation of UV-Visible Spectroscopic Method for the Estimation of Levofloxacin Hemihydrate in Bulk and Marketed Formulation. International Journal of Institutional Pharmacy and Life Sciences. 2011;1(2):57-69.

34. Ji HY, Jeong DW, Kim YH, Kim HH, Sohn DR, Lee HS. Hydrophilic Interaction Liquid Chromatography Tandem Mass Spectrometry for the Determination of Levofloxacin in Human Plasma. J. Pharm. Biomed. Anal. 2006;41(2):622-627.

35. ICH Harmonized Tripartite Guidelines. Validation of Analytical Procedures: Methodology (Q2B).

36. ICH Harmonized Tripartite Guidelines. validation of analytical Methods and Definitions and Terminology. Q2A.

37. ICH Harmonized Tripartite Guideline. Stability Testing of New Drug Substances and Products Q1A (R2). 2003.

38. Radadiya R, Patel N, Ribadia C. Development and validation of RP- 
HPLC method for simultaneous estimation of Cefixime trihydrate and Levofloxacin hemihydrate in bulk drug and in combined dosage form. Inventi Rapid: Pharm Analysis \& Quality Assurance. 2013; 899/30

39. Dhandhukia V, Tiwari P, Godavariya N. Development and validation of RP- HPLC method for the simultaneous estimation of cefixime trihydrate and levofloxacin hemihydrate in marketed formulation. Int. Res.
J. pharm. 2013;4(6):81-83.

40. Gaikwad SN, Londhe NB, Chaudhari PD, Shelke TT, Wayal SR. Development and Validation of RP-HPLC Methods for Simultaneous Estimation of Cefixime Trihydrate and Levofloxacin Hemihydrate in their Combined Tablet Dosage Form. Inventi Rapid: Pharm Analysis \& Quality Assurance. 2014(4):1-10. 